\title{
Pernkopf's atlas: Should unethically obtained life-saving data be discarded?
}

\author{
SUNIL K. PANDYA
}

\begin{abstract}
Dr Pernkopf's Topographische anatomie des menschen (Topographical anatomy of man), in four volumes, was originally published in German. It had taken the author and his colleagues over twenty years to produce it, the first volume being published in 1937. It was translated into English in 1964. The atlas was received with uniform acclaim in Europe and America and praised for its accuracy and the quality of its illustrations.
\end{abstract}

A recent study compared its utility with that of Dr Frank Netter's Atlas of human anatomy, first published in 1989, with its 7th edition out in 2018. "The respondents (nerve surgeons) found Pernkopf 's atlas having both greater anatomical detail (range 79\%-91\%) and greater utility for surgery (range 66\%- $82 \%$ ) when compared with Netter's $(P<.001)$ in all plate comparisons." $(1)$

Internationally renowned and respected neurosurgeon, Dr M Gazi Yasargil - not given to handing out praise lightly - said in 2004 of this atlas, "Pernkopf's work, in particular ... Vol. 4 (800 pages, 218 figures) is of fantastic quality and is appreciated worldwide." (2)

Surgeons continue to use Dr. Pernkopf's atlas to plan their operations (3). A recent example is its use in the treatment of a 13-year-old Israeli schoolboy (4).

This essay discusses whether it is rational to refuse to use data and publications that are accurate and likely to help in treating patients. Since such information can save lives, should we spurn it because it was based on information obtained unethically?

\section{Eduard Pernkopf}

Pernkopf (1888-1955) was born in a small village in lower Austria, the son of a country doctor. He received his medical degree from the Vienna Medical School in 1912 and taught anatomy thereafter. He succeeded his teacher, Ferdinand

Author: Sunil K Pandya (shunil3@gmail.com), Department of Neurosurgery Jaslok Hospital \& Medical Centre, Dr. G. V. Deshmukh Marg, Mumbai 400026.

To cite: Pandya SK. Pernkopf's Atlas: Should unethically obtained life-saving data be discarded? Indian J Med Ethics. 2020 Oct-Dec; 5(4) NS: 319-26. DOI: 10.20529/IJME.2020.088.

Published online first on August 22, 2020.

Manuscript Editor: Sanjay A Pai

Peer Reviewers: Ido Solt and an anonymous reviewer

(c) Indian Journal of Medical Ethics 2020
Hochstetter (1861-1954) as director of the Second Anatomy Institute in Vienna from 1933 onwards.

The Viennese Anatomy Institute had been divided into two departments in 1870. Anatomy 1 was clinically-oriented and led by Jewish scientists. The chairmen of Anatomy 2 tended towards nationalism and anti-Semitism. During the 1920s and 1930s, there was much antagonism between students from the two departments. In 1938, Anatomy 1 and 2 were reunited under the chairmanship of Pernkopf.

Pernkopf was described as an obsessive worker and demanding supervisor. He developed his dissection and illustration techniques using skilled artists quite early in his career. His personal routine of 18 -hour work days was, in his later years, focused completely on the atlas (5).

Pernkopf joined the National Socialist German Workers, or Nazi Party, in 1933. He joined the Storm Troopers, or Brown Shirts, a year later. One month after Nazi Germany invaded Austria in 1938, Pernkopf was made dean of the medical faculty in Vienna. From 1943 to 1945, he was Rektor Magnificus (president) of the University of Vienna.

From 1938 onwards, he was highly placed in the hierarchy of the Nazi party in Vienna. His speeches endorsed the Nazi emphasis on eliminating the unfit and "defective" from the population. Under his dispensation, all professors were required to swear an oath of loyalty to Hitler (6).

By the end of World War II, 38,000 doctors in Germany were members of the Nazi party and more than $7 \%$ of all physicians were members of the SS (Schutzstaffel or protection squadron). Serving the Nazi party advanced their academic careers, enabling them to carry out research and experiments and to write theses (7).

Pernkopf's deemed function under the Nazi regime was to lead the country to better state and racial health. The doctor was to be a servant of the nation and his greatest responsibility was not to the health of the individual patient, but to the health of the state.

Bruns and Chelouche (8) point out that a variant of medical ethics was very much a part of the medical curriculum under the Nazi regime (1939-1945). "The appointed lecturers were mostly ... members of the Nazi Party and imparted Nazi political and moral values in their teaching. These values included the unequal worth of human beings, the moral imperative of preserving a pure Aryan people... and the priority of public health over individual-patient care." 
The end of World War II resulted in several reverses for Pernkopf. He was dismissed as head of the Institute of Anatomy on May 10, 1945 (6). In August that year, he and his artist Batke were arrested by the American military. He was never charged with war crimes, but was sentenced to hard labour for three years in an American prison camp for war criminals near Salzburg. He continued to work on his atlas during imprisonment. On his release, Dr. Hans Hoff, a Jewish physician and Director of the Institute of Neurology in Vienna, allotted him two rooms for his work.

The atlas was all that kept him alive. Once again, he brought together his artists. In 1952, he published the section entitled Der Hals (The neck).

Pernkopf's student and post-war successor as Director of the Second Anatomy Institute - Hermann von Hayek - praised Pernkopf's love of music. He referred to his composition of an unpublished symphonic drama and called him a great teacher, researcher and human being (5).

Pernkopf died on April 17, 1955, from a haemorrhagic stroke whilst working on the fourth volume of his book. The last two volumes were brought out by Werner Platzer, regarded by many as his protégé.

Despite Pernkopf's long fall from grace, his burial turns out the entire faculty. He is celebrated by fellow professors as a perfectionist, a stirring teacher and the impresario of what many increasingly regard as the world's greatest anatomy book. (9)

\section{The Pernkopf atlas}

The first edition of Volume 1 was published in 1937. Currently available volumes of the atlas are of the 2 nd and subsequent revised editions (10).

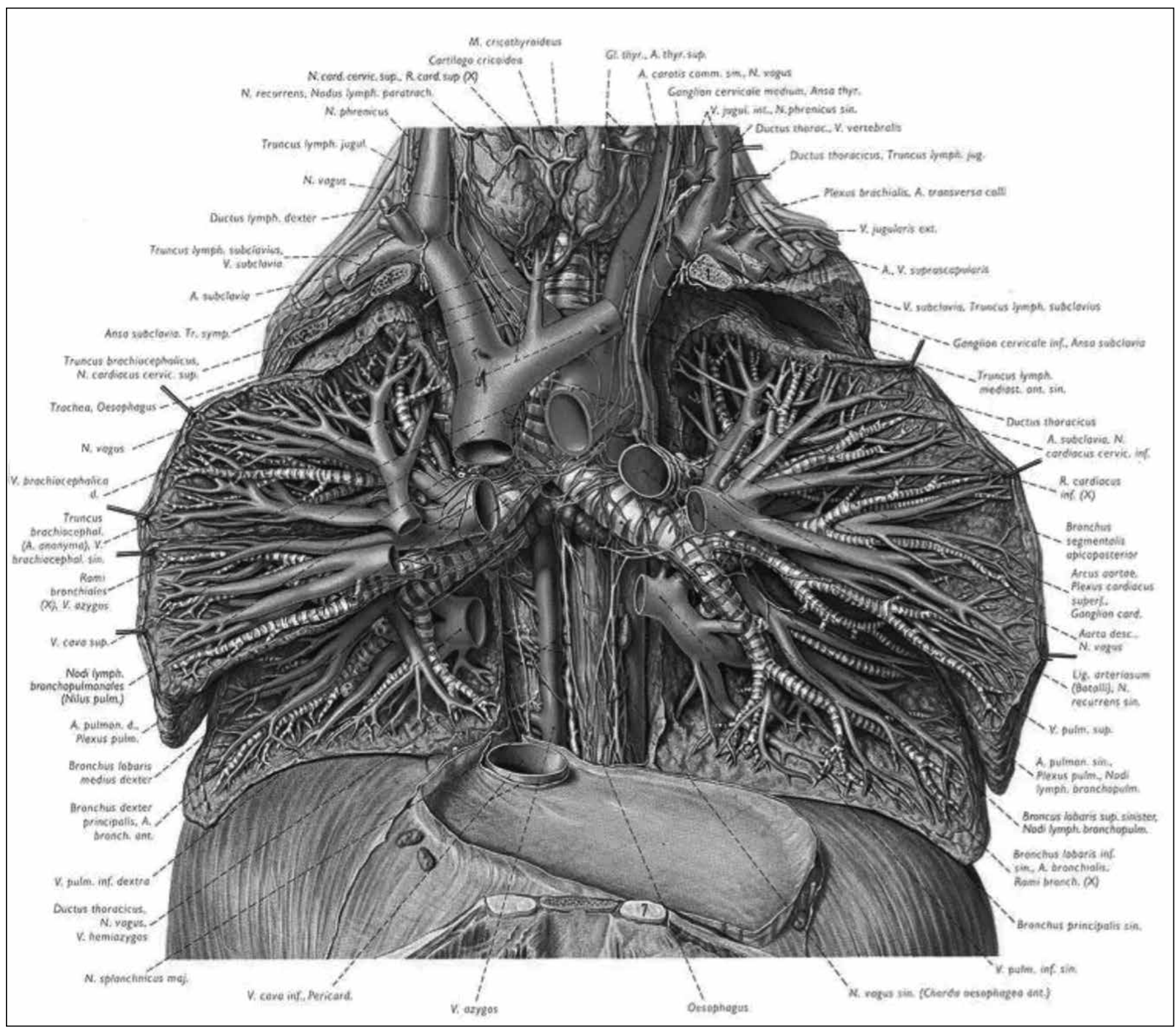

Detailed illustration of the dissected lower neck and chest from Pernkopf's atlas. From CODEX 99 - under a Creative Commons CC BY-NC-SA 4.0 license. 
Paterniti (9), an American investigative writer, provides graphic descriptions of the creation of this atlas and of Pernkopf's work on it.

Needing a dissection guide for his anatomy students, Pernkopf started out with the creation of a laboratory manual. Studying other anatomy texts, he found them outdated or unsatisfactory. He upscaled his project to provide the definitive atlas on human anatomy. This magnum opus, in four volumes, contained 800 paintings by eleven carefully selected artists. The technique of four colour separation was refined for his purpose. (Full colour photographs are separated into components, corresponding to the four primary colours cyan, magenta, yellow, and black. During printing, halftone dots of each of these four colours in varying densities are overprinted, the various combinations producing the wide range of reproducible colours. A different printing plate needs to be made of each colour and this, in turn, requires separate negatives or positives.)

Pernkopf wrote the text by hand. His wife typed it out. Assisting Pernkopf were the best graphic designers and artists in Vienna, among them Erich Lepier, Ludwig Schrott, Karl Endtresser and Frank Batke. About half of the original illustrations in the anatomical atlas were not created during the Nazi years. Some were made before 1937 and others after 1945. The dates of creation as well as the source of the bodies used as models for 350 paintings are unclear (5).

When dissections were performed for the illustrations to be included in the book, Pernkopf was "driven by ideas of accuracy and clarity". His publishers, Urban and Schwarzenberg, shared his dedication and vision.

Paterniti (9) also tells us of the search for Franz Batke - the last of Pernkopf's artists - by Professor David Williams who taught medical illustration at Purdue University. On meeting him, Williams wrote in his journal, "I am truly beginning to see this man as a genius." After studying art under Batke and reviewing Pernkopf's atlas, Williams praised it as "the standard by which all other illustrated anatomic works will be measured." Paterniti too appears to have been enthralled by the work:

The book is blindingly beautiful, an exaltation, a paean and a eulogy all at once. Page after page, the human body unfolds itself, and with each page the invisible becomes visible, some deeper secret reveals itself. (9)

So who is Pernkopf? If he's taciturn with his painters, it is because he maintains the utmost professionalism. A dreamer, an intellect, a lover of music, he is in the workshop early in the morning and late at night: He is simply an overwhelming presence. The Book becomes both his great unwritten symphony and, slowly, his madness. (9)

\section{The supply of corpses for dissection in Vienna}

Michael Atlas (11) provides details on the controversy regarding Pernkopf and his anatomical atlas:

The piece that really sparked the current controversy about the Pernkopf atlas was a letter to the editor of JAMA in
November 1996 signed by a professor of dental surgery from Columbia University and a professor of family and community medicine from the University of Toronto... Most pointedly they said that the precise origins of the cadavers used in Pernkopf's work are unknown, but evidence suggested they may have been victims of political terror. It is known that the Anatomy Institute of the University of Vienna received the cadavers of prisoners executed at the Vienna District Court and of others put to death at Gestapo execution chambers in Linz, Munich, and Prague. (11)

In 1998, the Jewish Holocaust Remembrance Authority requested an enquiry by the University of Vienna and that Pernkopf's history and a commemoration of the victims of the Nazis be included in future editions of the atlas.

The final report of the Pernkopf Commission of the Faculty Senate of the University of Vienna was issued on 1 October 1998. The investigation revealed that the Institute of Anatomy received at least 1,377 bodies of executed persons, including 8 victims of Jewish origin... On the basis of a general decree of February 18th, 1939, the bodies of persons executed were assigned to the Department of Anatomy of the nearest university for the purposes of research and teaching... No proof could be found that bodies had been brought to the Vienna Department of Anatomy from the Mauthausen (concentration) camp complex... The presumption and suspicions that some of the illustrations might be of prisoners of war or Jewish victims are based predominantly on impressions which strike the critical observer. In these cases, however, the investigation was able neither to prove nor to disprove the suspicions. Because of the systematic practice of making specimens anonymous, it seems likely that a final clarification of such suspicions will not now be possible. (11)

It is relevant to study how bodies had been acquired for dissection in Vienna before Pernkopf's tenure. Buklijas provides an excellent historical review (12).

Vienna was the site of the earliest recorded anatomical dissection outside the Mediterranean, preceding cities in today's Germany and Switzerland by almost a century. Unclaimed bodies and those of executed criminals, those dying of suicide and duelists, were used for this purpose. In Vienna, anatomies were performed first sporadically, and from 1537 annually, by a faculty member in the Allgemeine Krankenhaus der Stadt Wien - Vienna's large teaching hospital - and in the presence of medical students, doctors, apothecaries, surgeons, and learned men from the faculty of arts.

The bodies of executed criminals and paupers formed the bulk of the corpses used for anatomical and pathological studies up to the 19th century. Around 1850, the Allgemeine Krankenhaus was itself supplying 2000 corpses annually to the medical faculty. (The mortality rate in the hospital was $13.4 \%$ in the 1850s.). The hospital accommodated thousands of the sick poor. Emperor Joseph II decreed that the use of the bodies of these patients for medical education was a fair repayment for the free medical care they had received in the hospital. 
These corpses were treated with respect. In the 1850s, the society of St. Joseph of Arimathaea, named after the Biblical character who buried the body of Christ after crucifixion, organised and paid for the burial of dissected cadavers from the anatomical institute. "It replaced linen bags, in which the remains had traditionally been buried, with wooden coffins. Between 1857 and its dissolution in 1917, the Arimathaea became such an integral part of anatomy that anatomical cadavers became known as Arimathaealeichen" ('Arimathaea corpses'). This overcame the objection of the Roman Catholic church regarding the ultimate fate of the bodies."(12)

Nineteenth-century Vienna was renowned for its medical facilities. High standards of education and research, easy access to corpses for anatomical and pathological studies, and to patients with a variety of diseases attracted students from all over the western world.

For religious and political reasons, Jewish bodies were kept out of the reach of anatomists. Up to the 1920s, few Jewish bodies were subjected to dissection.

Pringle (13) provides details on the procedure under the Nazi dispensation. From 1938, anatomists at the University of Vienna made arrangements with local Nazi officials to receive the bodies of prisoners shot in the Gestapo rifle range or guillotined in Vienna's court building. If the medical school morgue was full, court officials postponed the executions (5).

Eduard Pernkopf's anatomical atlas, celebrated for its art but notorious for using the cadavers of victims of the fascist regime in the 1930s and 1940s, was the last in a tradition that went back to the nineteenth century. (13)

Whilst working with the aged Batke, one of Pernkopf's artists, Williams asked whether death-camp cadavers were used in the book. The old man became enraged and denied it vehemently. Simon Wiesenthal, Holocaust survivor and founder of the Jewish Documentation Centre, examined the records and his conclusions confirmed Batke's statement (9).

\section{Arguments for and against banning the atlas}

Michael Atlas (11) and Paterniti (9) summarise these well.

Scott Norton, Chief of Dermatology at the Walter Reed Institute of Research $(14,15)$ was placed in a dilemma when he found two volumes of Pernkopf's atlas in his department.

Norton referred to two book reviews. The first was in the New England Journal of Medicine (1990): "The publication of this third edition of the Pernkopf Anatomy testifies to the success that this classic atlas has met with among anatomists throughout the world... This outstanding book should be of great value to anatomists and surgeons. It is in a class of its own and will continue to be valued as a reference work." The second was in the Journal of the American Medical Association (1990): "The majority of the illustrations in this atlas are truly works of art, demonstrating by their clarity and precision the best in collaboration between master medical artists and skillful anatomic prosectors."
Norton noted that outside the University of Vienna, the story of Pernkopf and his atlas was largely unknown until the mid-1990s, when several reports led to investigations of the university's wartime practices.

Norton went about his task systematically. He collected background information on the atlas, distributed it to all members of his department and held a meeting after they had studied it. He pointed out, "Just as Andreas Vesalius's De humani corporis fabrica and Gray's Anatomy blur the line between science and art, Pernkopf's Anatomy maps the human body in exquisite detail that has won praise from generations of medical illustrators." He did not hold back information on Pernkopf's Nazi links and the sources of bodies for anatomical dissections. He quoted Helmut Gruber (then the Viennese school's deputy dean) that it was $99 \%$ certain that Pernkopf's atlas did NOT contain any drawings of Jews or other victims of concentration camps. He also quoted Richard Panush who had stated in a letter to the Journal of the American Medical Association in 1996: "(We) decided to expunge it (the atlas) from our collection... I believe that our moral obligation to society, to victims and survivors of Nazism, and to posterity is to repudiate Pernkopf and all that he represented..."

Norton then asked his colleagues whether it was acceptable for them to use the atlas.

The consensus reached by the department was that the atlas should not be retained in the department library as it was tainted and the information in it was not unique. The volumes were therefore transferred to the special collection in Walter Reed's main library because of its place in medical education and ethics. Library users were to be permitted to use it as "fully expunging the book hearkens to Nazi-era book burnings."

Norton commented that this consensus "inserted an uncomfortable moral relativism. After all, anatomists historically have obtained their models from the gallows and graveyard. Would Pernkopf's atlas be less tainted if the cadavers were from executed hardened criminals, say, child murderers, rather than those whose crimes were political?" He also posed another question, "Can a scientific or an artistic achievement be separated from the manner by which it was attained?" $(14,15)$

Bagatur (16) explains the rationale for the condemnation by the medical community of any use of knowledge derived from Nazi biomedical research. The use of such data corrupts the institution of medicine itself. He referred to the disfavour with which such eponyms as Reiter's syndrome, Hallervorden-Spatz syndrome and Asperger's disease are viewed today because of the Nazi associations of the persons after whom they are named.

Many of those who lost family members and friends in the Nazi concentration camps could not see the atlas as a repository of anatomical accuracy and beauty. For them, "the Book is nothing but a dirty crime scene, violated bodies that might include her brethren. The artists are no better than vultures over their carrion."(9) 
Some, like Abraham Foxman, national director of the AntiDefamation League, said that the research findings of heinous crimes or atrocities should not be used, even if it would do good, because it would retrospectively cleanse the atrocity and possibly justify similar acts in the future.

Kenneth Mellanby, then reader in medical entomology at the London School of Hygiene and Tropical Medicine, was appointed the British Medical Journal's first ever foreign correspondent to cover the Nuremberg medical trials. Mellanby had induced and studied scabies on conscientious objectors who had volunteered to be human guinea pigs. His attitude to the victims of Nazi medical crimes was, "the victims were dead; if their sufferings could in any way add to medical knowledge and help others, surely this would be something they themselves would have preferred." (17)

The accuracy and superlative quality of illustrations in Pernkopf's atlas have been lauded by all reviewers.

Michael Atlas and others believe that the use of the atlas itself is the most fitting tribute to those who died for it. "It is ironic retribution for the Jewish cadavers (or whoever died for whatever beliefs) to be used to illustrate a Nazi's anatomic atlas and be immortalized by it. Using this atlas allows these cadavers to speak to us from half a century ago. They make us reexamine and again repudiate the Nazi beliefs that created a society that killed them."(11)

Edward B Hutton, Jr, president of Waverly, Inc, was the American publisher of the atlas. The stand taken by him is of interest. In a November 1996 letter to JAMA, Hutton said his company continued to publish the Pernkopf atlas because of its scientific merit and because, to date, no concrete evidence had been found to substantiate Pernkopf's use of cadavers originating from Nazi concentration camp victims. Hutton acknowledged that Pernkopf was an avowed Nazi and that while Hutton and his company renounced Pernkopf's abhorrent views, they "separate Pernkopf, the man, from the work because of the lack of evidence as to the true origin of the cadavers used in the atlas."(11)

Garrett Riggs (18) echoed the feelings of many when he said, "Just as I can in no way condone the beliefs of Pernkopf and his Nazi cronies, neither can I deny the beauty, grace and precision of the images they produced."

Howard Israel (19) presented arguments, supported by many, that if some benefit could be derived from the use of the atlas today, to save a life or enable a surgeon to perform more skillfully, its use would honor those who suffered and sacrificed their lives. Such an argument might also maintain that not using tainted knowledge when it might help make better medical decisions might be actually unethical. Israel noted that there was no indication to the unsuspecting user that the book had any link to Nazi medicine, and he viewed suppression of the work as inappropriate and reminiscent of the book burnings that took place in Nazi Germany.
Paterniti (9) describes David Williams' visit to the repository in which the paintings used for the atlas are stored. Werner Platzer, who completed the last two volumes, showed Williams the nineteen binders stuffed with 800 original works of art.

But this time in their presence, he is not exactly euphoric. If he feels a deep sense of fulfillment in seeing these paintings one last time, he also feels a strange sadness. When it is over, when the sun dips below a building and a streetlight blinks on in the window, he is almost trembling. He pulls out a handkerchief, removes his glasses and wipes his face. His hair is slightly disheveled. He exhales, looks once at the oversize binders against the wall, presses his lips tightly together and then turns his back and leaves the room.

It is also important to remain within the bounds of reason. What is one to make of the controversy regarding the United States National Library of Medicine's Visible Human Project? The person who became the male Visible Human was Joseph Paul Jernigan. Jernigan was a convicted murderer (11). On July 3,1981 , he stabbed and shot to death a seventy-five-year-old man, who surprised him during a robbery. He was executed on August 5,1993 . He had willed his body to the Texas Anatomy Board, but almost certainly did not know he was a candidate for the Visible Human Project at the time of his death. Only after the body had been selected and processed did the committee choosing the body realize that they had selected an executed prisoner convicted of murder. The use of this particular cadaver raises the question of whether the project glamorises a convicted murderer, making him appear more sympathetic by allowing him to perform a service to society through no effort of his own. The Visible Human Male is, after all, a rather heroic, perhaps even a noble figure. Neither the National Library of Medicine nor the Colorado team identified Jernigan as the Visible Human male. However, his date and cause of death, as well as his state of origin were public information. His identity has been widely known and reported.

The announcement that the subject was an executed prisoner brought an interesting response from, of all places, the University of Vienna, specifically a group from the Department of Emergency Medicine. These doctors maintained that the death penalty and medical participation in an execution were unethical and that informed consent by the executed person did not dispel the unethical basis of the material used in this project. They called for the immediate withdrawal of the anatomical images as morally necessary (11)

\section{Nazis not alone in committing medical crimes}

Among the more heinous medical crimes, one must include the Japanese Unit 731 operating in occupied China, during World War II. It went under the relatively innocuous title of Army Epidemic Prevention Research Laboratory. In fact, under Surgeon General Shiro Ishii, it experimented in chemical and biological weapons. Details on the activities can be found in Wikipedia and papers available on the internet. Suffice it to say that Chinese prisoners were vivisected after they had been infected with a variety of diseases. Experiments on 
amputation, removal and transplantation of organs and the breeding of plague-infested fleas were only some of their other activities. These experiments continued up to the end of World War II. It is important to note that General Douglas MacArthur, Supreme Commander of the Allied Powers, secretly granted immunity to the physicians of Unit 731 in exchange for providing America, but not the other wartime allies, with their research on biological warfare and data from human experimentation (20).

Lest we feel superior to researchers during World War II, let us not forget the secret laboratories in China, Russia, the USA, Britain and other countries which continue, even today, to invent, experiment on and build stockpiles of deadly poisons, viruses and other pathogens.

\section{Would regulations and guidelines have averted the atrocities committed by the medical community in Nazi Germany?}

This question is especially relevant when we consider Nazi Germany where following the rules was mandatory.

Intrepid researchers, among whom John Hunter (1728-1793) stands out, usually experimented first upon themselves. His celebrated experiment on the transmission on venereal disease is well known. Others, such as Philippe Ricord (18001889) experimented on patients. The concept of informed consent had not yet evolved.

Albert Neisser (1855-1916) of Breslau, a leading dermatologist and famed for his discovery of Neisseria gonorrhoeae, attempted prevention of syphilis in 1892. He injected serum from a syphilitic patient into girls aged $10-24$ years, and into prostitutes. The liberal newspaper Münchner Freie Presse included information on Neisser's study in its ongoing discussion on human experimentation in hospitals. Debate in the Prussian parliament followed, where Rudolph Virchow (1821-1902) defended Neisser. The case was investigated by a court which ruled that Neisser should have sought the express consent of the patients. The Prussian government, after seeking expert opinion, issued path-breaking regulations on human experimentation in 1900 (21).

Moll and Krischel (21) quote from this report:

"... that medical interventions for purposes other than diagnosis, therapy, and immunization are absolutely prohibited, even if all other legal and ethical requirements for performing such interventions are fulfilled if: (1) the person in question is a minor or is not fully competent on other grounds;

(2) the person concerned has not declared unequivocally that he consents to the intervention; (3) the declaration has not been made on the basis of a proper explanation of the adverse consequences that might result from the intervention..."

They point out that under the Prussian culture "...it would be unthinkable that those ministerial directives would not have been treated with the utmost respect and introduced and obeyed in the most rigid way..."
And yet, a few decades later, Nazi Germany wilfully flouted these laws that remained operational.

One more example will suffice to show that those in power will contravene regulations when it suits their convenience or purpose.

The Nuremberg code was drafted after detailed discussions on Nazi atrocities and its ten points delivered as a verdict by the judges on August 20, 1947. In 1999, Horner analysed subsequent medical research and concluded:

...when the Nuremberg Code was published after the trial it continued to be ignored by many doctors for some thirty years afterwards. Indeed its central principle of informed consent has itself been eroded by subsequent international agreements on the ethics of medical research... (22)

America - in the forefront of the Nuremberg trials - had itself started the infamous infection of at least 5128 vulnerable Guatemalans with syphilis, gonorrhea and chancroid from 1946 and intentionally infected 1308 of these subjects between 1946 and 1948. The "research" was conducted by the Public Health Service and was funded by the National Institutes of Health. "The public had no knowledge of the experiments for more than half a century." (23) The Public Health Service of the U.S. Government had started the now notorious 'Tuskegee Study of Untreated Syphilis in the Negro Male' in 1932 and continued the study for 40 years!

Sadly, the promulgation of codes does not prevent unethical research.

\section{Summing up responses to the arguments against Pernkopf}

Appleyard (24), discussing the arts in general and writing on Christmas Eve, posed the question: Should we love the art if the artist is a monster?

He came to certain conclusions. Good or great art may be made by people who have done something horribly wrong. He quoted Roger Crisp, professor of moral philosophy at Oxford. "...Imagine if more and more revelations came out, so almost every great artist was morally tainted. Would we stop looking at art? I don't think so."

Appleyard asked, "What about Caravaggio, a murderer, a street hoodlum and one of the greatest artists of the Renaissance?" Waldemar Januszczak, art critic, felt that Caravaggio's art "has such enormous power and depth, carries so much religious conviction, that the darkness of its creator feels irrelevant." Appleyard also reminds us of Paul Gauguin "a paedophile racist, running around with these 13-year-old girls who become his so-called wives. Many scholars think it completely compromises you when you look those doeeyed, brown bodies and how they were representative of a culture of racism and colonialism." Tamar Garb, professor of the history of art at University College, London, commented that the history of art would have been different if there had been no Gauguin just as the history of cinema would have 
been different without Roman Polanski. (Polanski's reputation on the basis of his films such as Rosemary's baby, Pianist and Chinatown was marred by the accusation that he had raped a 13-year-old girl in 1977.)

Perhaps we should follow the principle used by Roland Barthes "the most influential aesthetic thinker of the 1970s. For him, once a work of art is made, the creator vanishes, becoming an irrelevance."(24)

The controversy over Pernkopf's atlas has resulted in some good. It provoked a historical and ethical analysis of the study and teaching of anatomy in Austria and Germany during the Nazi era and prompted philosophical debate. Hildebrandt (5) discusses these aspects and points out that in the case of this atlas the dilemma was especially poignant as the volumes under discussion provided unparalleled anatomical illustrations that remain useful to surgeons and students alike. She refers to the more recent criticisms of another German anatomist, who had once served on the faculty of the University of Heidelberg - Gunther von Hagens, who has been accused of using bodies of executed criminals from China (25).

Hildebrandt's conclusions (5) are rational and thoughtprovoking. Pernkopf's atlas is:

...the product of the very human mind of an obsessive perfectionist who would have pursued his work under any political circumstances. Indeed, the first and the last parts of the atlas were not created during the time of the NS regime in Austria but before and after under very different political and material conditions... a ban could not atone the great evil committed by human beings on other human beings. Rather, it is up to a new human generation to glean good from this murky history by continuing to use Pernkopf's atlas in a rational, historically conscious manner."

As she points out, the atlas can be used to teach not only anatomy but also history and ethics.

Yee and co-workers (26) discussed the continued use of the atlas with historians and religious authorities. Rabbi Joseph Polak, a Holocaust survivor and Chief Justice of the Massachusetts Rabbinical Court, was one of the experts consulted. The general conclusions were that the use of the atlas could be permitted under the Jewish principle of Pikuach Nefesh - the saving of human life (27).

I found the statements made by Dr Susan Mackinnon, who continues to use the atlas when performing complex operations on nerves, relevant:

I would think that as an ethical surgeon I would take it as a given that I should use whatever educational resource I thought would help me to maximise a successful outcome and that my patient would expect that of me. In my experience, it would set back detailed nerve surgery tremendously if these books are lost."(3)

\section{Conclusion}

When scientific data is obtained unethically, the means can only be condemned. There can never be a justification for such practices as were used by the Nazi medical experimenters, that violated all ethical principles.

That said, what is to be done to the invaluable, life-saving data yielded by such unethical studies? The victims of unethical practices have already passed away. We do them no harm by using the data.

We have two options. Erase all such data from all our medical repositories in such a manner that they can never be used by anyone. We shall then have jettisoned life-saving information and practices. This step may result in the worsening of patients who could have been helped by such information or even result in the loss of their lives. How does this help humanity?

The second option is to use the life-saving data and practices whilst remaining fully aware of the means by which they were obtained. In teaching institutes in particular, whenever such data is used to help the patient, a tribute is paid to the victims from whom this beneficial information had been obtained. This will also impress ethical principles upon young minds.

In making such use, we are remembering and honouring the victims even as we ameliorate symptoms and save lives.

\section{Acknowledgements}

Dr Anantanarayanan Raman (Australia) carefully went through my final draft and made several improvements.

I am grateful to Drs Reeta Mani (Bengaluru) and Bindu Desai (USA) for obtaining the full texts of references beyond my reach.

The anonymous referee to whom this paper was sent for review made excellent suggestions. I have incorporated information based on them.

\section{References}

1. Yee A, Coombs DM, Hildebrandt S, Seidelman W E, Coert J H, Mackinnon $\mathrm{S}$ E. Nerve surgeons' assessment of the role of Eduard Pernkopf's Atlas of topographic and applied human anatomy in surgical practice. Neurosurgery. 2019 Feb1;84(2):491-8.

2. Yasargil MG, Ture U, Yasargil DCH. Impact of temporal lobe surgery. (Editorial). J Neurosurg. 2004 Nov; 101(5):725-38.

3. BakerK.Eduard Pernkopf:the Nazi book of anatomy still used by surgeons. 19 August 19[cited 2020 Aug 15]. Available from https://www.bbc. com/news/health-49294861\#: :text=Eduard\%20Pernkopf\%3A\%20 The $\% 20 \mathrm{Nazi} \% 20$ book\%20of\%20anatomy $\% 20$ still\%20used $\% 20$ by\%20surgeons,-By\%20Keiligh\%20Baker\&text=When\%20nerve\%20 surgeon $\% 20$ Dr $\% 20$ Susan,20th $\% 20$ Century $\% 20$ book $\% 20$ of $\% 20$ anatomy.

4. Kershner I. In Israel, modern medicine grapples with ghosts of the Third Reich. The New York Times. 2020 May 12[cited 2020 Aug 15]. Available from: https://www.nytimes.com/2020/05/12/world/middleeast/nazimedical-text-israel.html

5. Hildebrandt S. How the Pernkopf controversy facilitated a historical and ethical analysis of the anatomical sciences in Austria and Germany: a recommendation for the continued use of the Pernkopf atlas. Clin Anat. 2006 Mar;19(2):91-100

6. Hubbard C. Eduard Pernkopf's Atlas of Topographical and Applied Human Anatomy the continuing ethical controversy. Anat Rec. 2001 Oct 15;265(5):207-11.

7. Silver JR. The decline of German medicine 1933-1945. J R Coll Physicians Edinb. 2003;33:54-66

8. Bruns F, Chelouche T. Lectures on inhumanity: teaching medical ethics in German medical schools under Nazism. Ann Intern Med. 2017; 166(8): 
591-5.

9. Paterniti M.The most dangerous beauty. GQ 2002 Sep 28 [cited $2020 \mathrm{Apr}$ 18]. Available from: https://www.gq.com/story/pernkopfs-anatomynazi-history

10. Pernkopf E. ed, Ferner $\mathrm{H}$, transl Monsen $\mathrm{H}$. Atlas of topographical and applied human anatomy. Volume 1. Head and neck. 2nd revised ed. Baltimore-Munich:Urban \& Schwarzenberg; 1980.

11. Atlas M C: Ethics and access to teaching materials in the medical library: the case of the Pernkopf atlas. Bull Med Libr Assoc. 2001 Jan;89(1):51-8

12. Buklijas T. Culture of death and politics of corpse supply: anatomy in Vienna. 1848-1914 Bull Hist Med. 2008 Fall; 82(3):570-607

13. Pringle H. Anatomy. Confronting Anatomy's Nazi past. Science $2010 \mathrm{Jul}$ 16;329(5989):274-6.

14. Norton SA: On first looking into Pernkopf's atlas. (Part 1). Arch Dermatol. 2001 May:137(5):549-51

15. Norton SA: On first looking into Pernkopf's atlas. (Part 2). Arch Dermatol. 2001 Jul:137(7): 867-8.

16. Bagatur E. Nazi medicine - Part 2: the downfall of a profession and Pernkopf's anatomy atlas. Clin Orthop Relat Res. 2018 Nov; 476(11):21237.

17. Weindling P. Human guinea pigs and the ethics of experimentation: the $B M J$ 's correspondent at the Nuremberg medical trial. BMJ. 1996 Dec 7 313(7070):1467-70.

18. Riggs G. What should we do about Eduard Pernkopf's atlas? Acad Med. 1998 Apr; 73(4):380-6.

19. Israel HA: The Nazi origins of Eduard Pernkopf's Topographische Anatomie des Menschen: the biomedical ethical issues. Reference Librarian. 1998; 29(61/62):131-46. Epub
20. Vanderbrook AJ. Imperial Japan's human experiments before and during World War Two. University of Central Florida. Electronic Theses and Dissertations, 2004-2019. 2013[cited 2020 Aug 19].p 55. Available from: https://stars.library.ucf.edu/etd/2589

21. Moll FH, Krischel M. Albert Neisser and the first Prussian directive on informed consent. In:Sakti Das MD, Ed.:Skeletons in the closet:Indignities and injustices in medicine. Linthicum, Maryland:The American Urological Association; 2012.

22. Horner JS. Retreat from Nuremberg? Can we prevent unethical medical research? Public Health. 1999; 113:205-10.

23. Rodriguez MA. First, do no harm: The US sexually transmitted experiments in Guatemala. Am J Public Health. 2013:103:2122-6.

24. Appleyard B. Should we love the art if the artist is a monster? The Sunday Times. 2017 Dec 24[cited 2020 Aug 15]. Available from: https:// www.thetimes.co.uk/article/should-we-love-the-art-if-the-artist-is-amonster-nvrdmg3hd

25. Harding L. Von Hagens forced to return controversial corpses to China. The Guardian. 2004 Jan 23[cited 2020 Aug 16]. Available from: https:// www.theguardian.com/world/2004/jan/23/arts.china

26. Yee A, Hildebrandt S, Seidelman WE, Mackinnon SE. Letter to the editor: Nazi medicine - Part 2: The downfall of a profession and Pernkopf's anatomy atlas. Clin Orthop Relat Res. 2018; 476:2465-6.

27. Polak JA. Vienna protocol for when Jewish or possibly-Jewish human remains are discovered. In: Czech H, Drumi C, Weindling P, Eds. Medical ethics in the70 years after the Nuremberg Code, 1947 to the present. Cent Eur J Med. 2018 [cited 2020 Apr 14]; 130: S239-43. Available from: https://link.springer.com/content/pdf/10.1007/s00508-018-1343-y.pdf

\section{Moving from clinical to pragmatic equipoise in health policy and systems research}

\section{VIJAYAPRASAD GOPICHANDRAN}

\section{Abstract}

Health policy and systems research refers to the research conducted on the formulation, impact, organisation and functioning of health policies, and how to optimise the functioning of health systems and policies towards achieving health for all. There is emerging scholarship on the ethics of conducting such health policy and systems research. Ethics of health policy and systems research, though similar to the ethics of traditional clinical research in many ways, has several important distinctions. In traditional clinical research on human participants, where two treatments or interventions are compared, clinical equipoise is an important ethical consideration. This refers to

Author: Vijayaprasad Gopichandran (vijay.gopichandran@gmail.com), Assistant Professor, Department of Community Medicine, ESIC Medical College and PGIMSR, KK Nagar, Chennai 600078 INDIA.

To cite: Gopichandran V. Moving from clinical to pragmatic equipoise in health policy and systems research. Indian J Med Ethics. 2020 Oct-Dec;5(4) NS: 326-9. DOI: 10.20529/JMME.2020.77.

Published online on July 20, 2020.

Manuscript Editor: Sandhya Srinivasan, Veena Johari

( ) Indian Journal of Medical Ethics 2020 the genuine uncertainty among professional peers on whether one of the interventions is better than the other. This uncertainty is in the biomedical efficacy of the intervention. Unless such equipoise exists, clinical research is said to be unethical from the benefit-risk balance and justice perspectives. In health policy and systems research, the question of clinical equipoise is often not relevant. This article will describe the condition of clinical equipoise in health policy and systems research, its applications and challenges.

Key words: clinical equipoise, health policy and systems research, pragmatic equipoise

\section{Introduction}

Health policy and systems research (HPSR) refers to all research that attempts to understand the way health systems function and methods to strengthen them $(1,2)$. The important goals of HPSR are to understand the dynamics of functioning of a health system, to study how interventions impact the functioning and outputs of the system, to evaluate the influence of policies on health system functions and outcomes and to strengthen the health system through interventions and policies that are grounded in evidence. Therefore, HPSR is a multidisciplinary enterprise involving contributions from healthcare providers, public health experts, policy makers and 